\title{
NILAI RESISTIVITAS DENGAN VARIASI JARAK DI TEMPAT PEMROSESAN AKHIR SAMPAH GUNUNG KUPANG BANJARBARU
}

\author{
Hardiono, Imam Santoso, Arifin \\ Jurusan Kesehatan Lingkungan Poltekkes Kemenkes Banjarmasin \\ Jl.H.M.Cokrokusumo No.1A Kota Banjarbaru \\ Email: dionhar@gmail.com
}

\begin{abstract}
:
Abstrak: Nilai resistivitas dengan variasi jarak di tempat pemrosesan akhir sampah Gunung Kupang Banjarbaru. Tempat Pemrosesan Akhir Sampah (TPA) Gunung Kupang Banjarbaru terletak di Kecamatan Cempaka. Pembuangan sampah di TPA ini rata rata 1000 m3 atau 65 - 85 ton per hari. Pada daerah ini diduga terdapat rembesan air lindi. Tujuan penelitian ini diperolehnya gambaran pola distribusi akumulasi rembesan air lindi di sekitar TPA Gunung Kupang berdasarkan nilai resistivity (tahanan jenis listrik). Metode penelitian secara eksperimen yaitu dengan menetapkan variasi jarak dari lahan Tempat Pemrosesan Akhir Sampah kemudian dilakukan pengukuran nilai resistivity lapisan tanah dan batuan. Perlakuan yang dilakukan adalah variasi jarak dari TPA mulai dari 0, 10 meter dan 40 meter sedangkan variabel yang diteliti adalah nilai resisistivitas dari lokasi yang berhubungan TPA. Hasil penelitian menunnjukkan bahwa rerata nilai Resistivitas pada lintasan A (0 m dari TPA) $13.075 \Omega \mathrm{m}$, pada lintasan B (10 m dari TPA ) $30.995 \Omega \mathrm{m}$ dan pada Lintasan C (40m dari TPA) 91.3 TPA $91.3 \Omega \mathrm{m}$. Ada perbedaan bermakna rata-rata nilai Resisistivitas ( $\mathrm{p}=0.056)$. Rata-rata nilai resistivitas lintasan $\mathrm{A}(0 \mathrm{~m}$ dari TPA) dengan Lintasan $\mathrm{B}(10 \mathrm{~m}$ dari TPA $)$. tidak ada perbedaan bermakna $(p=0.74)$ dan ada rembesan lindi pada jarak $10 \mathrm{~m}$ dari TPA. Rata-rata nilai resistivitas lintasan A(0 m dari TPA) dengan Lintasan C (40 m dari TPA ) ada perbedaan bermakna $(p=0.027)$. Rembesan cairan lindi terbanyak memanjang dari jarak 0 sampai 100 meter pada lintasan A memanjang pada jarak 60 - 72.5 m pada lintasan B dan pada lintasan C memanjang pada jarak $80-140 \mathrm{~m}$, dengan nilai resistivitas antara $2-8 \Omega \mathrm{m}$. Disarankan penggunaan metode penyelidikan geolistrik konfigurasi Dipole dipole Res2Dinv D bisa dipakai untuk evaluasi tentang kemungkinan cemaran lindi dari Tempat pemrosesan Akhir sampah.
\end{abstract}

Kata Kunci : Resistivitas, Jarak dan Tempat Pemrosesan Akhir Sampah.

\section{PENDAHULUAN}

Aktivitas

manusia dalam

memanfaatkan alam selalu meninggalkan sisa yang dianggap sudah tidak berguna lagi sehingga diperlakukan sebagai barang buangan yaitu sampah. Sampah merupakan polutan umum yang dapat menyebabkan turunnya nilai estetika lingkungan, membawa berbagai jenis penyakit, menurunkan sumber daya, menimbulkan polusi, menyumbat saluran air dan berbagai akibat negatif lainnya, sehingga manusia menyingkirkan sampah sejauh mungkin dari aktivitas manusia yang biasa disebut Tempat Pemrosesan Akhir (TPA) sampah.
Upaya Pengelolaan sampah telah dilakukan mulai dari timbulan, penyimpangan, pengumpulan, pengolahan , pengangkutan dan pembuangan akhir sampah dengan memperhatikan aspek estetika, kesehatan masyarakat, lingkungan, teknologi, ekonomi dan pemberdayaan masyarakat. Akhir dari pengelolaan sampah adalah pembuangan akhir sampah dan bila cara pembuangan Akhir Sampah tidak memperhatikan aspek lingkungan maka dampaknya adalah pencermaran lingkungan antara lain adalah adanya pencemaran tanah dan air tanah.

Tempat Pemrosesan Akhir (TPA) Gunung Kupang Banjarbaru merupakan 
salah satu contoh TPA yang terletak di Kecamatan Cempaka. TPA ini mempunyai luas 10 Ha dimana sebelumnya merupakan lahan kosong. TPA ini telah beroperasi sejak beberapa tahun yang lalu dengan pembuangan sampah rata rata $1000 \mathrm{~m} 3$ atau 65 - 85 ton per hari. TPA ini dahulu direncanakan menggunakan Sanitary landfill tapi pengolahannya tidak lebih dari open dumping dan controlled landfill Sampah yang dibuang di tempat ini adalah sampah organik sebanyak $70 \%$ dan anorganik $30 \%$, Selain itu TPA ini juga dilengkapi dengan kolam cairan lindi.

Pada daerah ini diduga terdapat rembesan air lindi yang merupakan polutan sampah yang dapat mencemari tanah di daerah sekitar TPA Banjarbaru termasuk kota sedang sehingga Metode pembuangan Akhir hanya disarankan Controllled landfill, dimana pada lapisan dasar sebelum ditimbun sampah tidak ada lapisan geomembrane atau lapisan kedap air sehingga diduga ar lindi merembes ke lapisan batuan dibawahnya.

Salah satu metode yang banyak dipakai dalam studi pencemaran tanah adalah metode geolistrik. Metode ini dilakukan melalui pengukuran beda potensial yang ditimbulkan akibat injeksi arus listrik ke dalam bumi. Sifat-sifat suatu formasi dapat digambarkan oleh tiga parameter dasar yaitu konduktivitas listrik, permeabilitas magnet, dan permitifitas dielektrik(1). Sifat konduktivitas batuan berpori dihasilkan oleh sifat konduktivitas dari fluida yang mengisi pori, interkoneksi ruang pori dan sifat konduktivitas dari

interfase butiran dan fluida pori (1)'

Berdasarkan pada harga resistivitas listriknya, suatu struktur bawah permukaan bumi dapat diketahui material penyusunnya(2). Metode geolistrik cukup sederhana, murah dan sangat rentan terhadap gangguan sehingga cocok digunakan dalam eksplorasi dangkal. Desain sistem monitoring menggunakan resistivitas listrik sangat penting untuk mendeteksi aliran air tanah(3).

Metode penelitian ini secara analitik yaitu melakukan pengukuran nilai resistivity lapisan batuan disekitar TPA gunung Kupang dengan menggunakan alat ukur resisitivitimeter dan konfigarasi elektroda metode 2 D (dipole-dipole Resistivity(4). Survei resistivitas 2D adalah pengukuran resistivitas batuan dengan menyuntikkan arus listrik melalui 2 elektroda arus dan kemudian mengukur potensial listrik yang terjadi melalui 2 elektroda potensial. Posisi ke empat elektroda ini kemudian dipindah-pindah sepanjang garis pengukuran untuk mengukur variasi resistivitas batuan di sepanjang garis pengukuran. Kedalaman survei dapat ditambah dengan memperbesar jarak (spasi) antara elektroda-elektroda ${ }^{(4)}$.

Tujuan penelitian ini untuk memperoleh gambaran pola distribusi akumulasi rembesan air lindi di sekitar TPA Gunung Kupang berdasarkan nilai resistivity (tahanan jenis listrik).

\section{BAHAN DAN CARA PENELITIAN}

Metode penelitian secara eksperimen yaitu dengan menetapkan variasi jarak dari lahan TPA kemudian dilakukan pengukuran nilai resistivity lapisan tanah dan batuan dengan dengan menggunakan alat ukur resisitivitimeter dan konfigurasi elektroda metode 2 D (dipole-dipole Resistivity). Pengukuran resistivitas 2D adalah pengukuran resistivitas batuan dengan menyuntikkan arus listrik melalui 2 elektroda arus dan kemudian mengukur potensial listrik yang terjadi melalui 2 elektroda potensial. Posisi ke empat elektroda ini kemudian dipindah-pindah sepanjang garis pengukuran untuk mengukur variasi resistivitas batuan di sepanjang garis pengukuran. Kedalaman survei dapat ditambah dengan memperbesar jarak (spasi) antara elektroda-elektroda. Untuk variasi jarak dari TPA meliputi jarak 0 meter , 10 meter dan 20 meter.

Variabel yang diteliti terdiri dari perlakuan : Variasi Jarak sumber cemaran lindi disekitar TPA Gunung Kupang dan sebagai variabel dependen yaitu nilai resistivitas.

Populasi dalam penelitian ini adalah seluruh lahan di sekitar lahan tempat penimbunan sampah di TPA gunung Kupang.Sampel penelitian berupa titik titik pengukuran yang ada disatu sisi sekitar TPA 
Gunung Kupang yang ditentukan secara dengan perkirakan ada cemaran lindi. Variasi jarak dengan TPA ditentukan 0 meter, 10 meter dan 40 meter dan ulangan sebanyak 20 kali , sehingga sampel data sebanyak $3 \times 20$ data $=60$ sampel.

Bahan/alat yang digunakan terdiri dari Resistivitimeter yang berguna untuk memberikan harga beda potensial (V) dan kuat arus (I). Patok untuk mengetahui penempatan elektroda yang akan dipasang. Palu digunakan untuk memukul elektroda potensial dan elektroda arus di tanah. Accu (elemen kering) sebagai sumber arus. Elektroda (elektroda potensial dan elektroda arus). Meteran digunakan untuk mengukur panjang lintasan yang akan diteliti. Kabel listrik digunakan sebagai kabel penghubung. Alat Komunikasi (HT). Tabel data gunanya sebagai tempat menulis data hasil pengukuran. Alat tulis menulis digunakan untuk menulis data dari hasil pengukuran dan Software Res2Dinv digunakan untuk menampilkan gambar penampang .

Teknik pengambilan data melalui pengukuran nilai resisitivitas dari titik sampel dilakukan dengan cara melakukan survei resistivitas 2D adalah pengukuran resistivitas batuan dengan menyuntikkan arus listrik melalui 2 elektroda arus dan kemudian mengukur potensial listrik yang terjadi melalui 2 elektroda potensial . Posisi ke empat elektroda ini kemudian dipindahpindah sepanjang garis pengukuran untuk mengukur variasi resistivitas batuan di sepanjang garis pengukuran. Kedalaman survei dapat ditambah dengan memperbesar jarak (spasi) antara elektroda-elektroda, dalam hal ini sampai dengan $150 \mathrm{~m}$. Survei resistivitas 2D memvariasikan spasi elektroda-elektroda tanpa titik simetri (titik tengah). Dalam survei dipergunakan konfigurasi dipoledipole dengan spasi elektroda terkecil $5 \mathrm{~m}$. memperlihatkan konfigurasi dasar dipoledipole beserta rumus untuk menentukan tahanan jenis terukur (apparent resistivity).
Sebelum pengukuran lapangan, direncanakan dahulu konfigurasi dan urutan pengukuran agar ketelitian (resolusi) dan kedalaman target eksplorasi tercapai. Titik kedalaman dari setiap pengukuran di suatu posisi disebut titik datum. Sedangkan perbandingan antara jarak pasangan elektroda arus ke pasangan elektroda potensial terhadap spasi terpendek disebut $n$. Besaran $n$ ini mengindikasikan kedalaman pengukuran, semakin besar $n$, maka semakin dalam daya tembus pengukuran. Kontur dari harga tahanan jenis terukur dari datum-datum disebut pseudosection.

Analisis data secara analitik menggunakan Uji Anova satu arah yaitu menganalisis harga tahanan jenis/ nilai resistivitas $(\Omega \mathrm{m})$ tiap titik pengukuran pada jarak dari TPA $0 \mathrm{~m}, 10 \mathrm{~m}$ dan $40 \mathrm{~m}$ sebagai lintasan, yaitu menganalisis perbedaan nilai resisitivitas lokasi pengukuran berdasarkan jaraknya dengan lahan TPA, Sedangkan untuk gambaran grafik data tahanan jenis dari tiap titik pengukuran dikorelasikan dengan istilah geologi dengan menggunakan software RES2DINV sehingga mendapat gambaran rembesan lindi pada lokasi penyelidikan (TPA Gunung Kupang)

\section{HASIL DAN PEMBAHASAN}

1. Hasil Pengukuran Nilai Resistivitas di daerah Penelitian.

TPA Gunung Kupang metode pengolahan sampah awalnya menggunakan metode open dumping" dan disempurnakan dengan metode controlled landfill.

Hasil pengukuran nilai Resistivitas di daerah penelitian dilakukan di 3 lintasan.Tiap lintasan diambil salah satu sampel kedalaman sekitar $7.5 \mathrm{~m}$ yang diulang 20 titik secara horisontal . Lintasan A terletak dekat TPA, yang berjarak 0 meter dari TPA, pada lintasan B berjarak sekitar 10 meter dari TPA sebelah Utara dan pada lintasan C berjarak 40 meter dari TPA, karena adanya kolam. 
Tabel 1. Nilai Hasil Pengukuran Resistivitas

\begin{tabular}{|c|c|c|c|}
\hline $\begin{array}{c}\text { Titik } \\
\text { Pengamatan }\end{array}$ & $\begin{array}{c}\text { Lintasan A (0 mTPA ) } \\
\Omega \mathrm{m}\end{array}$ & $\begin{array}{c}\text { Line B (10m TPA }) \\
\Omega m\end{array}$ & $\begin{array}{c}\text { Line C (40 m TPA) } \\
\Omega \mathrm{m}\end{array}$ \\
\hline 1 & 54.95 & 40.3 & 51.3 \\
\hline 2 & 6.0 & 33.2 & 1130 \\
\hline 3 & 2.4 & 2.8 & 879.2 \\
\hline 4 & 2.3 & 31.4 & 14.4 \\
\hline 5 & 3.7 & 26.9 & 53.8 \\
\hline 6 & 5.3 & 32.1 & 56.5 \\
\hline 7 & 3.3 & 33.1 & 47.1 \\
\hline 8 & 15.9 & 45.0 & 376.8 \\
\hline 9 & 13.4 & 61.3 & 50.2 \\
\hline 10 & 7.3 & 89.7 & 47.1 \\
\hline 11 & 8.9 & 80.7 & 14.4 \\
\hline 12 & 9.2 & 44.3 & 28.9 \\
\hline 13 & 8.8 & 6.2 & 9.4 \\
\hline 14 & 12.0 & 16.6 & 22.1 \\
\hline 15 & 12.7 & 19.4 & 3.3 \\
\hline 16 & 13.2 & 17.6 & 7.0 \\
\hline 17 & 19.9 & 4.5 & 7.1 \\
\hline 18 & 7.9 & 15.7 & 32.9 \\
\hline 19 & 42.9 & 15.0 & 7.5 \\
\hline 20 & 28.1 & 4.1 & 4.0 \\
\hline Nilai rata-rata & 13.9075 & 30.995 & 91.3 \\
\hline Nilai P & & 0.056 & \\
\hline
\end{tabular}

Dari hasil tersebut rata rata hasil penelitian tidak ada perbedaan, pada linatasan A dekat dengan TPA rata-rat 13.9 $\Omega \mathrm{m}$ sedangkan pada lintasan B sekitar $10 \mathrm{~m}$ dari TPA rata-rata nilai resistivitas $30.9 \Omega \mathrm{m}$ dan pada lintasan yang jauh dari TPA sekitar $40 \mathrm{~m}$ dari TPA nilai reistivitas ratarata $91.3 \Omega \mathrm{m}$.

Tabel 2. Hasil Perbandingan rata - rata Nilai Resistivitas antar jarak pengukuran dan TPA Gunung Kupang

\begin{tabular}{llrrrrr}
\hline & & & & \multicolumn{2}{c}{$95 \%$ Confidence Interval } \\
\cline { 6 - 7 } & & Mean & & & \multicolumn{1}{c}{ Upper } \\
(I) JARAK & (J) JARAK & Difference (I-J) & Std. Error & \multicolumn{1}{c}{ Sig. } & Lower Bound & \multicolumn{1}{c}{ Bound } \\
\hline Jarak 0mTPA & Jarak 10m TPA & -17.08750 & 56.52541 & .764 & -130.2777 & 96.1027 \\
& Jarak 40m TPA & $-128.24250^{*}$ & 56.52541 & .027 & -241.4327 & -15.0523 \\
Jarak 10m TPA & Jarak 0mTPA & 17.08750 & 56.52541 & .764 & -96.1027 & 130.2777 \\
& Jarak 40m TPA & -111.15500 & 56.52541 & .054 & -224.3452 & 2.0352 \\
Jarak 40m TPA & Jarak 0mTPA & $128.24250^{*}$ & 56.52541 & .027 & 15.0523 & 241.4327 \\
& Jarak 10m TPA & 111.15500 & 56.52541 & .054 & -2.0352 & 224.3452 \\
\hline
\end{tabular}

*. The mean difference is significant at the 0.05 level.

Dari Tabel 2, terlihat bahwa hanya jarak $0 \mathrm{~m}$ dan $40 \mathrm{~m}$ terdapat perbedaan bermakna $\mathrm{p}<0,05(\mathrm{p}=0.027)$ sedangkan pada jarak $0 \mathrm{~m}$ dengan $10 \mathrm{~m}$ perbedaannya tidak bermakna ( $p=0.764$ Hasil pengukuran secara grafis lintasan A (jarak 0 meter dari TPA)sebagai berikut :

1. Hasil pengukuran pada lintasan A sebanyak 191 data dengan jarak antar lokasi 5 meter dengan konfigurasi Dipole 


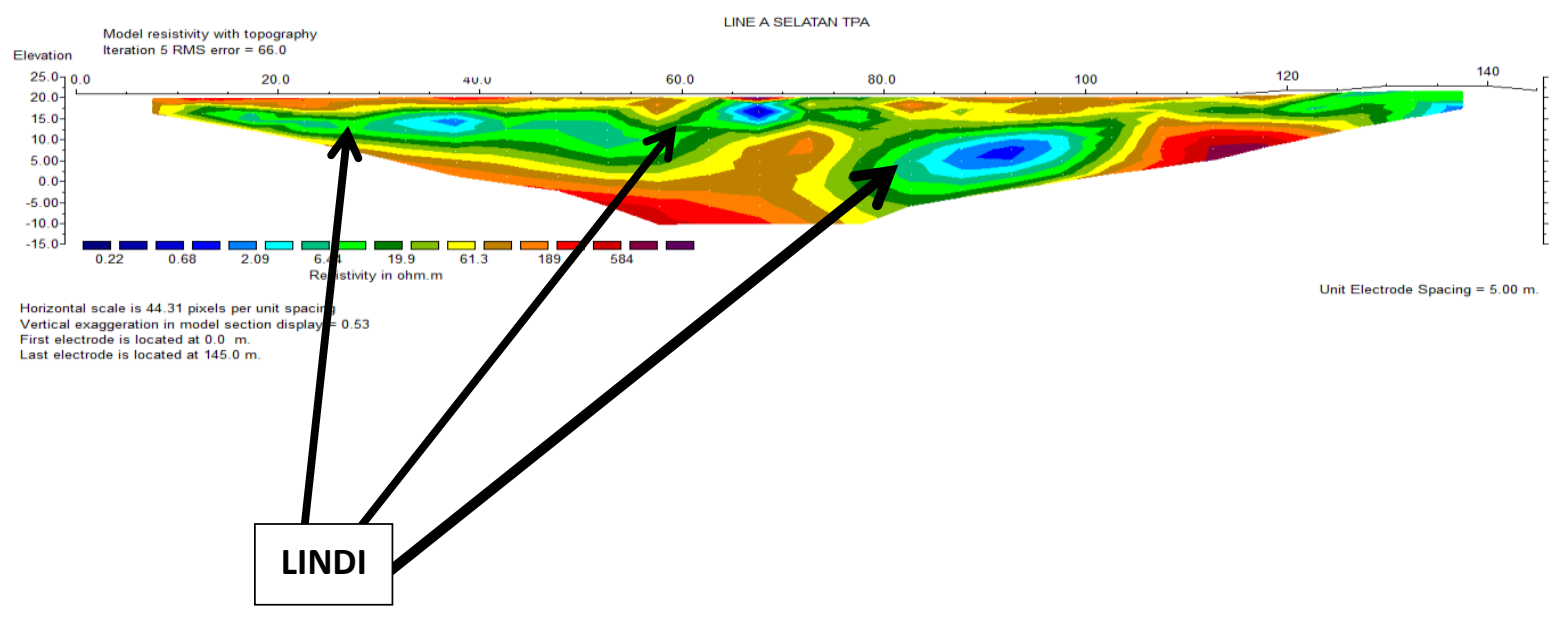

Gambar 1. Penampang model 2D dengan Lintasan A (jarak 0 dari TPA)

2. Pada Lintasan A dekat TPA

Lapisan lindi dengan nilai resistivity $0.22-6.44 \Omega \mathrm{m}$, terdapat pada jarak 30 $100 \mathrm{~m}$ dari titik awal dekat jalan dan pada titik sounding. Pada jarak 35,00 m lindi terdapat pada kedalaman $\quad 5.0 \quad-7.50 \mathrm{~m}$ dengan ketebalan lapisan sekitar $2.50 \mathrm{~m}$. Pada titik sounding65 - 70 lapisan lindi terdapat pada kedalaman $1,5-5,00 \mathrm{~m}$. Lapisan Lindi memiliki ketebalan $5.0 \mathrm{~m}$. Pada jarak 85 - 95 m lapisan lindi terdapaat pada kedalaman 5.25 - $15.25 \mathrm{~m}$ dengan kedalaman rata-rata $10 \mathrm{~m}$.

Kedalaman maksimum lindi pada Lintasan A dekat dengan TPA adalah $5,25-15,25 \mathrm{~m}$ pada kordinat LS 03응 29.876', BT $114^{\circ} 54.318^{\prime}$. Kedalaman minimum lindi adalah 5,00 -7,50 m pada jarak $30 \quad-35 \quad m$ dari titik awal pengukuran. Lapisan Lindi pada Lintasan-A memiliki kedalaman ratarata 5,25-15,25 m.

3. Penampangan lintasan B ( jarak 10 meter dari TPA).

Hasil pengukuran pada lintasan B yang berjarak $10 \mathrm{~m}$ sebelah Utara TPA dengan data sebanyak 191 data dengan jarak antar lokasi 5 meter dengan konfigurasi Dipole Dipole dan total panjang lintasan $150 \mathrm{~m}$. Kemudian dilakukan pemgolahan data dengan software Res $2 \mathrm{D}$ dengan hasil sebagai berikut : 


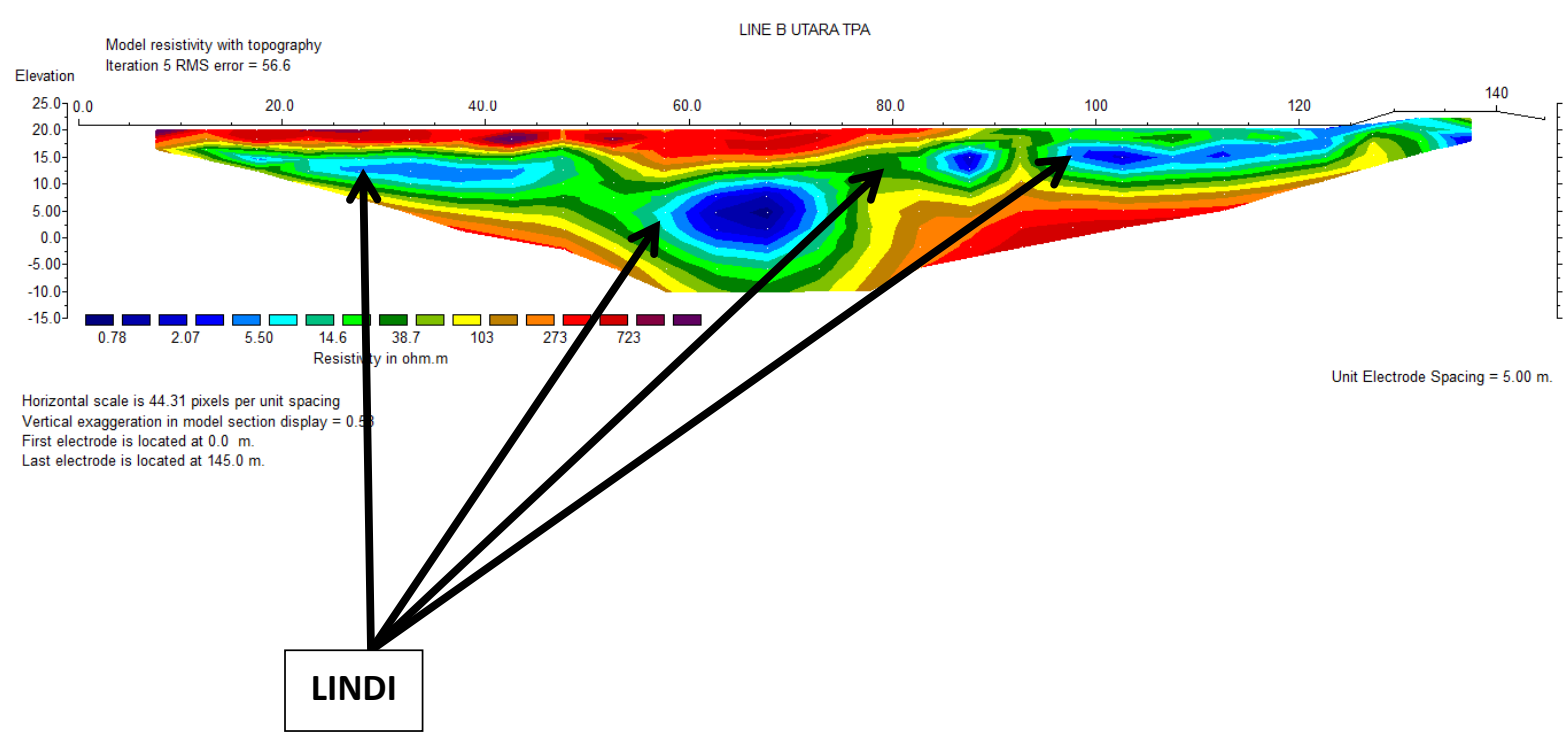

Gambar 2. Penampang model 2D dengan Lintasan jarak 10 dari TPA

4. Pada Lintasan-B (jarak $10 \mathrm{~m}$ dari TPA)

Lapisan lindi terdapat pada jarak 25 -

$45 \mathrm{~m}$ dari titik awal dan pada titik sounding pada kedalaman 5,0 -10,0 m dengan ketebalan lapisan 5,0 m. Pada titik sounding 60 - 75 m lapisan lindi terdapat pada kedalaman 10 - 20 m. Lapisan Lindi memiliki ketebalan $10 \mathrm{~m}$. Pada titik sounding $85-135 \mathrm{~m}$ lapisan lindi terdapat kealaman 0 - $5.25 \mathrm{~m}$, dengan kedalaman 5 $\mathrm{m}$. Kedalaman maksimum lindi pada lintasn $67.5 \mathrm{~m}$ adalah $10,-20,0 \mathrm{~m}$ pada koordinat LS $03^{\circ} 29.845$; $\mathrm{BT}^{\circ} 14^{\circ} 54.326^{\prime}$ Kedalaman minimum lindi adalah 5.0 - $10.0 \mathrm{~m}$ pada jarak 25- $45 \mathrm{~m}$ dari titik awal pengukuran. Lapisan Lindi pada Lintasan-A memiliki kedalaman rata-rata $5-15,5 \mathrm{~m}$.

5. Penampangan lintasan C ( jarak 40 meter dari TPA).

Hasil pengukuran pada lintasan C yang berjarak $40 \mathrm{~m}$ sebelah Utara TPA dengan data sebanyak 191 data dengan jarak antar lokasi 5 meter dengan konfigurasi Dipole Dipole dan total panjang lintasan $150 \mathrm{~m}$, kemudian diolah dengan menggunakan software Res $2 \mathrm{D}$, dengan hasil sebagai berikut.

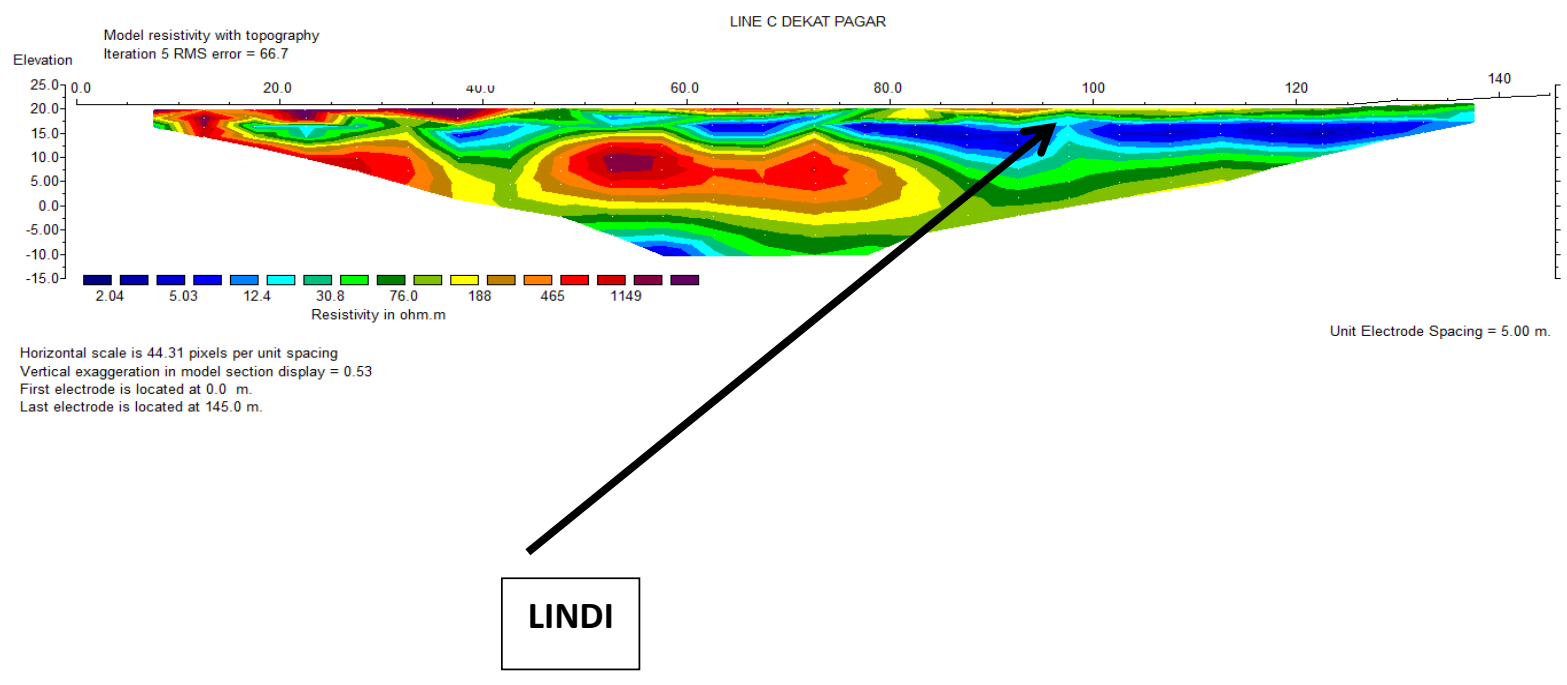

Gambar 3. Penampang model 2D dengan Lintasan jarak $40 \mathrm{~m}$ dari TPA 
6. Pada Lintasan-C(jarak $40 \mathrm{~m}$ dari TPA)

Lapisan lindi terdapat pada jarak 80 $135 \mathrm{~m}$ dari titik awal dan pada titik sounding pada kedalaman 2.50-5,0 m dengan ketebalan lapisan $2.50 \mathrm{~m}$.

Kedalaman maksimum lindi pada Lintasan-C adalaari $\mathrm{h} 5.50 \mathrm{~m}$ pada koordinat LS $03^{\circ} 29.823^{\prime}$ LS dan BT $114^{\circ} 22^{\prime} 54.332^{\prime} . . \quad$ Lapisan Lindi pada Lintasan-C memiliki kedalaman ratarata $2.5-7.50 \mathrm{~m}$.

\section{Pembahasan}

Nilai Resistivitas pada kedalaman 7.5 m dengan panjang lintasan $5-100$ m. Hasil Pengukuran Resistivitas pada titik sounding dengan kedalaman $7.5 \mathrm{~m}$ yang diulang sepanjang mulai meter 5 sampai 100 meter pada pinggir jalan sehingga terdapat 20 titik sounding.

Menggunakan uji Anova satu arah hasilnya ada perbedaan bermakna $(p=0.054)$ nilai rata-rata resistivitas masing-masing lintasan. Lintasan A yang berjarak 0 meter dari TPA, rata-rata nilai resistivitasnya adalah $13.907 \Omega \mathrm{m}$ dengan nilai minimum $2.3 \Omega \mathrm{m}$ dan maksmimum $54.9 \Omega \mathrm{m}$ yang terletak di meter ke 5. Pada lintasan B yang berjarak 10 meter dari TPA rata-rata hasil pengukuran $30.995 \Omega \mathrm{m}$ dengan nilai minimum $2.8 \Omega \mathrm{m}$ dan nilai maksimum $89.7 \Omega \mathrm{m}$. Pada lintasan $\mathrm{C}$ yang berjarak 40 meter sebelah Utara dari TPA nilai rata-rata resistivity adalah $91.3 \Omega \mathrm{m}$, nilai minimum $3.3 \Omega \mathrm{m}$ dan nilai maksimum $1130 \Omega \mathrm{m}$.

Secara umum makin jauh dari TPA nilai resistivitas pada kedalaman $7.5 \mathrm{~m}$ mempunyai nilai resistivitas makin tinggi. Nilai resistivitas ditafsirkan dengan lapisan tanah yang terdapat di dalamnnya. Makin tinggi nilai resisitivitas ditafsirkan sebagai lapisan batuan yang keras sehingga tidak bersifat konduktor, sebaliknya makin kecil mendekati angka lebih kecil dari $10 \Omega \mathrm{m}$ bersifat konduktor atau penghantar listrik. Pada cairan lindi rata-rata mempunyai nilai resistivitasnya rendah sekitar $2-6 \Omega \mathrm{m}$. Maka dapat disimpulkan secara statistik makin jauh dari TPA tidak terjadi rembesan lindi pada kedalaman $7.5 \mathrm{~m}$. Hasil Uji ststistik Anova satu arah menunjukkan perbandingan rata-rata nilai resistivitas pada lintasan A $(0 \mathrm{~m}$ dari TPA $)$ dan Lintasan $\mathrm{B}(10 \mathrm{~m}$ dari TPA $)$ tidak ada perbedaan bermakna $(p=0.74)$ sedangkan perbandingan nilai rata-rata resistivitas antara lintasan A (0m dari TPA) dan lintasan $\mathrm{C}(40 \mathrm{~m}$ dari $\mathrm{TPA})$ terdapat perbedaan bermakna ( $p=0.27)$. Hasil Pengolahan data secara grafis $2 \mathrm{D}$.

Secara Umum terdapat perbedaan nilai resististivitas dan dengan grafis yang diolah dengan software Res2Dinv.

1. Lintasan A (0 m dari TPA)

Pada lintasan A yang berjarak 0 meter dari TPA lapisan lindi memanjang dari titik sounding awal di pinggir jalan sampai meter ke 100 . Lapisan lindi kedalamnya mulai $2 \mathrm{~m}$ sampai $10 \mathrm{~m}$ dan yang terdalam pada jarak 80 sampai dengan $100 \mathrm{~m}$. Kedalaman lapisan lindi mulai $5 \mathrm{~m}$ sampai dengan 15 meter. Nilai resistiviti sekitar 2 $8 \Omega \mathrm{m}$. Grandis dan Yudistira (2002), melakukan penelitian di bekas TPA Pasir Impun Bandung dan berhasil memperkirakan penyebaran kontaminan cair dalam tanah yang diasosiasikan sebagai fluida konduktif dengan anomali konduktif (resistivitas kurang dari $10 \Omega \mathrm{m}$ ) menunjukkan akumulasi rembesan lindi yang dapat mencemari air tanah di sekitar daerah tersebut $(6)$.

2. Lintasan B ( $10 \mathrm{~m}$ dari TPA)

Pada lintasan B yang berjarak 10 meter dari TPA lapisan lindi memanjang dari titik sounding awal di pinggir jalan sampai meter ke 145 . Lapisan lindi kedalamnya mulai $5 \mathrm{~m}$ sampai $20 \mathrm{~m}$ dan yang terdalam pada jarak 60 sampai dengan $72.5 \mathrm{~m}$. Kedalaman lapisan lindi mulai $10 \mathrm{~m}$ sampai dengan 20 meter. Pada jarak 85 sampai jarak $140 \mathrm{~m}$ lapisan lindi mulai kedalaman 0 sampai $5 \mathrm{~m}$. Nilai resistiviti sekitar $2-8$ $\Omega \mathrm{m}$.

Grandis dan Yudistira (2002), melakukan penelitian di bekas TPA Pasir Impun Bandung dan berhasil memperkirakan penyebaran kontaminan cair dalam tanah yang diasosiasikan sebagai fluida konduktif dengan anomali konduktif (resistivitas kurang dari $10 \quad \Omega \mathrm{m}$ ) menunjukkan akumulasi rembesan lindi yang dapat mencemari air tanah di sekitar daerah tersebut ${ }^{(6)}$.

Penelitian yang dilakukan oleh Johanis (2002), yang menggunakan metode 
geolistrik resistivitas konfigurasi WennerSchlumberger dengan mengambil tiga lintasan sebagai titik-titik pengukuran, yaitu lintasan A terletak pada timbunan sampah, lintasan B berada antara timbunan sampah dan tanah, lintasan C berada di luar timbunan sampah. Hasil penelitian ini menunjukkan bahwa terdapat resistivitas rendah pada ketiga lintasan tersebut yang diduga merupakan daerah yang tercemar polutan cair yang dihasilkan oleh pembusukan sampah(7).

3. Lintasan C ( $40 \mathrm{~m}$ dari TPA)

Pada lintasan $\mathrm{C}$ yang berjarak 40 meter dari TPA lapisan lindi memanjang dari titik sounding awal di pinggir jalan sampai meter ke 80 - 145 . Lapisan lindi kedalamnya mulai $2 \mathrm{~m}$ sampai $7.5 \mathrm{~m}$. Nilai resistiviti sekitar 2 - $8 \Omega \mathrm{m}$.

Grandis dan Yudistira (2002), melakukan penelitian di bekas TPA Pasir Impun Bandung dan berhasil memperkirakan penyebaran kontaminan cair dalam tanah yang diasosiasikan sebagai fluida konduktif dengan anomali konduktif (resistivitas kurang dari $10 \Omega \mathrm{m}$ ) menunjukkan akumulasi rembesan lindi yang dapat mencemari air tanah di sekitar daerah tersebut(6).

Penelitian yang dilakukan oleh Johanis (2002), yang menggunakan metode geolistrik resistivitas konfigurasi WennerSchlumberger dengan mengambil tiga lintasan sebagai titik-titik pengukuran, yaitu lintasan A terletak pada timbunan sampah, lintasan B berada antara timbunan sampah dan tanah, lintasan $\mathrm{C}$ berada di luar timbunan sampah. Hasil penelitian ini menunjukkan bahwa terdapat resistivitas rendah pada ketiga lintasan tersebut yang diduga merupakan daerah yang tercemar polutan cair yang dihasilkan oleh pembusukan sampah. Pada lintasan $\mathrm{C}$ di TPA Gunung Kupang ini pada jarak sounding 0 sampai 100 meter nilai resistivitas rata-rata tinggi sekitar $91.3 \Omega \mathrm{m}$ sedangkan pada jarak sampai $140 \mathrm{~m}$ mempunyai nilai resisitivitas $2-10 \Omega \mathrm{m}^{(7)}$.

\section{KESIMPULAN DAN SARAN Kesimpulan}

Rata-rata nilai Resistivitas pada lintasan A (0 m dari TPA) $13.075 \Omega \mathrm{m}$, pada lintasan B (10 m dari TPA ) $30.995 \Omega \mathrm{m}$ dan pada Lintasan C (40m dari TPA ) 91.3 TPA $91.3 \Omega \mathrm{m}$. Ada perbedaan bermakna ratarata nilai Resisistivitas $(\mathrm{p}=0.056)$.

Rata-rata nilai resistivitas lintasan A(0 m dari TPA) dengan Lintasan B (10 m dari TPA) tidak ada perbedaan bermakna $(p=0.74)$ dan ada rembesan lindi pada jarak $10 \mathrm{~m}$ dari TPA.

Rata-rata nilai resistivitas lintasan $\mathrm{A}(0 \mathrm{~m}$ dari TPA) dengan Lintasan $\mathrm{C}(40 \mathrm{~m}$ dari TPA) ada perbedaan bermakna $(p=$ 0.027).

Rembesan cairan lindi terbanyak memanjang dari jarak 0 sampai 100 meter pada lintasan A, memanjang pada jarak 60 - 72.5 m pada lintasan B dan pada lintasan $\mathrm{C}$ memanjang pada jarak $80-140 \mathrm{~m}$.

\section{Saran}

Pemrosesan sampah Akhir di TPA Gunung Kupang untuk yang akan datang diharapkan menggunakan metode Sanitary Land Fill.

Perlu penelitian lebih luas metode geolistrik Res2Dinv untuk melihat cemaran lindi pada TPA yang lain yang telah menggunakan metode pemrosesan sampah metode sanitary land fill dengan variasi jarak lebih rapat dari TPA.

Metode penyelidikan Geolistrik Res2Dinv bisa dipakai evaluasi tentang kemungkinan cemaran lindi dari Tempat pemrosesan Akhir sampah.

\section{KEPUSTAKAAN}

1. Revil, A.,1988 "Nature of Surface Electrical Conductivity in Natural Sand, Sandstones, and Clays", Geophysical Research, 25, 691-694, (1998).

2. Telford. W.M.., Sheriff, R.E., Geldart, L.P.,1990 "Applied Geophysics", 2nd ed. New York, Cambridge University Press.

3. White, P.A.1994, "Electrode arrays for measuring groundwater flow direction and velocity", Geophysics, 59, 192-201

4. Loke, M.H.2001, "Electrical Imaging Surveys for Environmental and Engineering Studies, A practical guide to 2-D and 3-D surveys", Penang - Malaysia.

5. oke, M. H. 1997. A practical guide to 2-D and 3-D surveys (Online).http://www.geophysik unikoeln de/ studium /WS04/ vorlesung/env geoscience/ 
chapter2.pdf. diakses pada tanggal 14 Maret 2015.

6. Grandis, H dan Yudistira, T. 2002. Pencitraan Konduktivitas Bawah Permukaan dan Aplikasinya untuk Identifikasi Penyebaran Kontaminan. http://www.dikti.org/p3m/abstrakHB /AbstrakHB02.pdf

7. Johanis, S. B. 2002. Aplikasi Metoda Geolistrik dalam Pemantauan Pencemaran Lingkungan (Studi Kasus:Pasir Impun Bandung). 